\title{
Editorial
}

\section{Byssinosis: a disease or a symptom?}

Not only was respiratory disease among textile workers recognised by the father figures of occupational medicine, ${ }^{12}$ but it was also described by the nineteenth century English novelist Elizabeth Gaskell ${ }^{3}$ :

"Fluff?" said Margaret inquiringly.

"Fluff," repeated Bessy. "Little bits, as fly off fro' the cotton, when they're carding it, and fill the air till it looks all fine white dust. They say it winds round the lungs, and tightens them up. Anyhow, there's many a one as works in a carding-room, that falls into a waste, coughing and spitting blood, because they're just poisoned by the fluff."

How much more do we know?

The orthodox model of the natural history of byssinosis owes much to the studies of Schilling and his coworkers. ${ }^{45}$ After some years in the mill, a textile worker preparing or spinning cotton, flax, or hemp develops "chest symptoms" on the first day of work after a break - generally in Western countries a Monday (grade 1/2). As the disease progresses these symptoms become apparent every Monday (grade 1) and, later, on subsequent weekdays as well (grade 2). At that stage, it is believed, removal of the worker from that form of work would leave him free from symptoms and from any long term effects. Should he continue at work, permanent respiratory disablement may supervene (grade 3 ). This model of the natural history appears to have been constructed from a series of cross sectional studies of workers with different exposures to dust (different in both duration of exposure and concentration of dust) and at different stages of the "progression" of the disease. No major longitudinal studies covering the complete time span through to residual respiratory disability have been reported.

In the foregoing description the term chest symptoms has been used in describing the early stages for two reasons. Firstly, in byssinosis the symptoms are all important for there are no characteristic changes found from physical examination, radiography, or pulmonary function testing. Indeed, all the findings are frequently normal. Secondly, descriptions of the nature of the symptoms yield useful thoughts, and the attempts of Victorian clinicians to translate into words $^{6}$ their patients' indefinite sensations have

Address for reprint requests: Professor WR Lee, Department of Occupational Health, University of Manchester, Stopford Building, Manchester M139PT. recently been reviewed. ${ }^{7}$ With the advent of epidemiological studies in the 1950s the description of the symptoms was transferred from the patient to the investigator, so that the patient's response to questioning could be restricted to "Yes" or "No." The word tightness was chosen, with the result that most present day descriptions of the disease tell us that "tightness" is what the patient feels. This total reliance on a single symptom has led some investigators to look for more objective ways, such as measurement of $\mathrm{FEV}_{1}$, of assessing the disease. ${ }^{8}$ So we now have a model containing the presumptions that chest "tightness," generally accompanied by a fall in FEV ${ }_{1}$ over the day, appears at the start of the working week and that both the initial and the long term effects are stages of the same disease process. This model forms the basis of proposals for a medical surveillance programme for exposed workers put forward by a working party of the Health and Safety Executive. ${ }^{9}$ It is also the basis on which claims for disability are judged. Lately many of the presumptions in this model have been challenged and they were reviewed recently at a symposium organised by Dr Peter Elwood at the Medical Research Council Epidemiology Unit ${ }^{10}$ that offered to cast "new light on byssinosis."

Over a quarter of a century ago serial measurement over the working day showed that cardroom workers as a group had a diurnal fall in ventilatory function at the begining, but not at the end, of the working week. ${ }^{11}$ Shortly afterwards a small but detailed study showed that some workers might develop "chest tightness" without a corresponding diurnal fall in ventilatory capacity and vice versa. ${ }^{12}$ This dissociation was confirmed during a subsequent epidemiological study. ${ }^{13}$ It is perhaps surprising that no reports have appeared on the temporal relationship, over the first working day of the week, between the development of chest "tightness" and the concomitant development of ventilatory (or other) changes in persons who exhibit both.

Surprisingly to those studying occupational asthma, little work has been done on hyperreactivity of the airways in those with byssinosis, apart from one study some 20 years ago that showed that subjects with byssinosis did not react to inhaled histamine aerosols whereas another group, described as bronchitic byssinotics, did react. ${ }^{14} \mathrm{~A}$ later study, ${ }^{15}$ by Bouhuys and his group, showed that persons 
responding with a fall in ventilation to aqueous cotton bract extract did not exhibit more sensitivity to inhaled histamine than those not responding to cotton bract extract. They concluded that "responders" to cotton dust extract do not suffer from clinical asthma. That study, however, is not comparable with the earlier one, which selected subjects according to their clinical history of byssinosis.

Another presumption in the orthodox model of byssinosis is that the disease leads to an increased mortality rate. Indeed, Schilling's seminal studies in the early 1950s stemmed from the observation of increased mortality in cotton workers, ${ }^{1617}$ and this was given credence by the accepted natural history of the disease (or, we now ask, was that picture of the natural history constructed, from the cross sectional studies, to accord with the observed increases in mortality?). This view was questioned a few years ago after a 10 year follow up of 1586 workers seen earlier in an investigation in Lancashire cotton mills. There had been just over 100 deaths and, whether for respiratory or circulatory disease or for "all causes", they were fewer than expected. ${ }^{18}$ Admittedly, the "healthy worker" effect cannot be dismissed but at least there was no prima facie evidence of serious respiratory mortality. At the same time, in the United States, a study in two cotton mills in North Carolina showed no excess of deaths from respiratory causes among the textile workers. ${ }^{19}$ Moreover, Elwood found no excess in mortality in a follow up of 2528 flax workers, $97 \%$ of whom were traced 16 years later. ${ }^{20} \mathrm{He}$ went on to ask whether, if mortality could not be shown to be increased, it was the most appropriate and sensitive index. Might there be respiratory disability affecting maybe the quality of life but not shortening it? Although he judged this to be unlikely he had gone on to conduct an investigation both of respiratory symptoms and of lung function in $890 \mathrm{ex}-$ cotton workers and in 1949 ex-flax workers. ${ }^{21}$ The only positive finding was that lung function was about $5 \%$ less in the ex-textile workers than in their neighbours who were not ex-textile workers. The concomitant observation, however, that the ex-textile workers were some $2 \mathrm{~cm}$ shorter than their neighbours suggested to him a possible deprivation among the textile workers that might be partly social and nutritional.

Are there any long term effects of working with cotton dust? A comparison of chronic respiratory symptoms and ventilatory function between English cotton workers (from towns with heavy atmospheric pollution at that time) and Dutch cotton workers (from a more rural environment) showed that although the prevalence of chronic bronchitis was higher in the former it was nevertheless present in some Dutch workers. ${ }^{22}$ It has been suggested that such an effect might be a form of industrial bronchitis. ${ }^{23}$ Such an idea finds support in the findings of Edwards, ${ }^{24}$ who has developed his earlier studies ${ }^{25}$ and described the histopathology in 43 subjects who had received industrial benefit for byssinosis. $\mathrm{He}$ found that although the proportions of gland, muscle, and cartilage in named bronchi are increased the figures are similar to those in patients with chronic bronchitis. Further, in this issue (p 6) Honeybourne and Pickering suggest that emphysema seen in those with byssinosis is due to concomitant cigarette smoking and is not a feature of the byssinosis.

These findings may be compared with the results of a prospective study from the Manchester Pneumoconiosis Panel* of 689 cotton workers accepted for disablement benefit (grades 2 or 3 ), who came mostly from mills spinning the coarser yarns. ${ }^{26}$ That part of the analysis concerned with smoking concentrated on the lifelong non-smokers and those who had continued to smoke through the follow up and who had $\mathrm{FEV}_{1}$ readings at their initial and final examinations. There was a continued loss of ventilatory capacity in those with byssinosis who had continued to smoke for up to 10 years after leaving contact with cotton dust. The continued loss also applied to non-smoking grade 2 byssinotic subjects but, curiously, not to nonsmokers with grade 3 byssinosis (no explanation was offered). After 10 years away from cotton dust neither the grade 2 nor the grade 3 byssinotic non-smokers showed a continued decline in $\mathrm{FEV}_{1}$ of more than the normal rate. If the respiratory disease of cotton and other textile fibre workers ("byssinosis") is, in fact, a mixture of three separate conditions - an acute symptom, an acute fall in ventilatory function, and a chronic respiratory disorder that may be called industrial bronchitis (but without an overall increase in mortality)-where are we to look for a cause? Or should we be looking for more than one cause? In his recent comprehensive review Morgan and his colleagues ${ }^{23}$ concentrated on studies relating to the fall in ventilatory function. Little seems to have been done to study the cause of the acute symptoms since the investigations some years ago based on the bronchial response to extracts of bract and pericarp. ${ }^{27} \mathrm{~A}$ different approach has recently been suggested by Hendrick, who points to similarities in the weekly symptom pattern between byssinosis and humidifier disorders. ${ }^{28}$ But fever is not a feature of byssinosis. The practical consequence of our ignorance of the causative agent or agents is that environmental standards (threshold limit values, control limits, etc) still have to be expressed in terms of concentration of "cotton dust" rather than in terms of any particular

*Now called the Manchester Medical Boarding Centre (Respiratory Diseases). 
component.

The implications for occupational medicine of this "new light" are interesting and could be far reaching. In the absence of a clear understanding of the causation and pathology, prevention will continue to depend on reduction or elimination of "cotton dust" or "flax dust" from the work room. No more specific advice can be offered to the industry.

If the initial symptoms of exposure to dust are no longer to be regarded as necessary precursors of long term effects, what would be the consequences for medical surveillance and for the award of benefit and compensation?

A system of routine medical surveillance based on the appearance of a set of symptoms (whether or not accompanied by a fall in $\mathrm{FEV}_{1}$ ) that are not linked to any subsequent respiratory disability, which the surveillance would be designed to prevent, would be not only scientifically unsound but also ethically wrongfor it would purport to offer advice or reassurance that was insecurely founded. In any case a further point should be considered. The clinieal diagnosis of byssinosis is not easy and requires careful, patient history taking. ${ }^{7}$ Would that be a feature of any proposed medical surveillance? If the elicitation of the all important symptoms were reduced to the annual or two yearly use of a questionnaire in which the patient's relevant answers were confined to "Yes" and "No" the results might depend on factors other than the patient's awareness of symptoms. The influence of such factors would need to be assessed before the value of such yearly answers could be accepted. For similar reasons, because of the considerable number of successful common law claims for byssinosis in recent years, future large epidemiological surveys may be subject to recall bias.

The problems are no less in the award of benefit or compensation. Essentially, current practice depends on the elicitation of a history of the appropriate initial symptom complex in appropriately exposed workers, with perhaps the demonstration of some respiratory disability. If the initial symptom complex is no longer to be considered as a necessary antecedent to the development of residual respiratory disability, on what grounds can a claim for byssinosis be assessed and distinguished from other causes of respiratory disability? Furthermore, if the suggestions are substantiated that eventual long term respiratory disability is not a feature of "byssinosis," what is benefit or compensation being paid for?

A compromise, though hardly a solution, was offered. Byssinosis as a prescribed disease might be grouped along with occupational asthma, although to those who see both diseases in their clinical practice they are quite distinct conditions. This latter view is supported by the study of the response of those with byssinosis to histamine aerosols ${ }^{14}$ discussed earlier. Nevertheless, a case can be made for considering under the same administrative heading these two prescribed diseases, each of which rests heavily for diagnosis on a distinctive clinical history, generally without changes in the chest radiograph or results of routine pulmonary functions tests. Both diseases may, in certain cases, be followed by long term respiratory disability.

Professor RSF Schilling (personal communication) drew attention to the National Coal Board pneumoconiosis compensation scheme which provides benefits for coalworkers' pneumoconiosis as a substitute for tort damages. A person accepts benefits under that scheme in place of the right to seek compensation in a common law claim (tort). With that scheme the trade unions have agreed not to support their members who decide to claim tort compensation instead of relying on the scheme's benefits. ${ }^{29}$ Could this be a solution for the textile industry?

Most symposia, a critic would remark, have one predictable outcome - the demonstration of a need for further work. This symposium is, for the reasons discussed, no exception, although the directions that future work might follow have been made more clear, particularly the need for longitudinal studies. Difficulties arising from the possible recall bias mentioned and also the contracting workforce, however, pose serious practical problems.

WR LEE

Department of Occupational Health, University of Manchester, Manchester M139PT TB STRETTON Manchester Royal Infirmary, Manchester M13 9WL

\section{References}

1 Ramazzini B. De morbis artificum diatriba mutinae. Modena, 1713. Reprinted, Turin: Edizioni Minerva Medica, 1933.

2 Thackrah CT. The effects of arts, trades and professions on health and longevity. 2nd ed. London: Longmans, 1832:144-8.

3 Gaskell E. North and south. First published 1854. London: Penguin, reprinted 1984:146.

4 Roach SA, Schilling RSF. A clinical and environmental study of byssinosis in the Lancashire cotton industry. $\mathrm{Br}$ J Ind Med 1960;17:1-9.

5 Schilling RSF, Vigliani EC, Lammers B, Valic F, Gilson JL. In: Akoun G, Beale HL, Earle KV, Moragas Redecilla A, Rodes de Sisternes L, eds. Proceedings of the XIVth international congress on occupational health, Madrid, 1963. Amsterdam: Excerpta Medica, 1964;2:137-45. (International congress series No 62.)

6 Kay JP. Observations and experiments concerning molecular irritation of the lungs as one source of tubercular 
consumption; and on spinners' phthisis. North of England Medical and Surgical Journal 1831;1:348-63.

7 Lee WR. Clinical diagnosis of byssinosis [Editorial]. Thorax 1979;34:287-9.

8 Bouhuys A, Schoenberg JB, Beck GJ, Schilling RSF. Epidemiology of chronic lung disease in a cotton mill comunity. Lung 1977;154:167-86.

9 Lyle WH. Pre-employment screening and monitoring of workers: practical and theoretical limitations. In: Elwood PC, ed. New light on byssinosis. Cardiff: Medical Research Council Epidemiology Unit, 1985:129-30.

10 Elwood PC. In: Elwood PC, ed. New light on byssinosis. Cardiff: Medical Research Council Epidemiology Unit, 1985:3-5.

11 McKerrow CB, McDermott M, Gilson JC, Schilling RSF. Respiratory function during the day in cotton workers: a study in byssinosis. $\mathrm{Br} J$ Ind Med 1958;15:75-83.

12 Massoud AAE. Pulmonary function in workers in the cotton spinning industry, University of Manchester, $\mathrm{PhD}$ thesis, 1964.

13 Berry G, McKerrow CB, Molyneux MKB, Rossiter CE, Tombleson JBL. A study of acute and chronic changes in ventilatory capacity of workers in the Lancashire cotton mills. Br J Ind Med 1973;30:25-36.

14 Massoud AAE, Altounyan REC, Howell JBL, Lane RE. Effects of histamine aerosol in byssinotic subjects. $B r J$ Ind Med 1967;24:38-40.

15 Schachter EN, Brown S, Zuskin E, Buck M, Kolack B, Bouhuys A. Airway reactivity in cotton bract-induced bronchospasm. Am Rev Respir Disease 1981;123:273-6.

16 Schilling RSF, Goodman N. Cardiovascular disease in cotton workers. Part 1. Br J Ind Med 1951;8:77-90.

17 Schilling RSF, Goodman N, O'Sullivan JG. Cardiovascular disease in cotton workers. Part 2. Br J Ind Med 1952;9:146-56.

18 Berry G, Molyneux MKB. A mortality study of workers in Lancashire cotton mills. Chest 1981;79, suppl.
19 Merchant JA, Ortmeyer CE. Mortality of employees of two cotton mills in North Carolina. Chest 1981;79, suppl: 6.

20 Elwood PC, Thomas HF, Sweetnam PM, Elwood JH. Mortality of textile workers. $\mathrm{Br} J$ Ind Med 1982;39:18-22.

21 Elwood PC, Sweetnam PM, Elwood JH, Campbell L. Respiratory symptoms and lung function in ex-cotton and flax workers. In: Elwood PC, ed. New light on byssinosis. Cardiff: Medical Research Council Epidemiology Unit, 1985:95-127.

22 Lammers B, Schilling RSF, Walford J. A study of byssinosis, chronic respiratory symptoms and ventilatory capacity in English and Dutch cotton workers, with special reference to atmospheric pollution. $\mathrm{Br} J$ Ind Med 1964;21:124-34.

23 Morgan WKC, Vesterhund J, Burrell R, Gee JBL, Willoughby WF. Byssinosis: some unanswered questions. Am Rev Respir Dis 1982;126:354-7.

24 Edwards CW, Carlile A. The pathology of byssinosis in Lancashire cotton workers. In: Elwood PC, ed. New light on byssinosis. Cardiff: Medical Research Council Epidemiology Unit, 1985:33-47.

25 Edwards C, McCartney J, Rooke G, Ward F. The pathology of the lung in byssinosis. Thorax 1975;30:612-23.

26 Rooke GB, Dempsey AN. Observations on byssinotics diagnosed in the United Kingdom between 1974 and 1980. In: Elwood PC, ed. New light on byssinosis. Cardiff: Medical Research Council Epidemiology Unit, 1985:69-94.

27 Taylor G, Massoud AAE, Lucas F. Studies on the aetiology of byssinosis. Br J Ind Med 1971;28:143-51.

28 Hendrick DJ. Contaminated humidifiers and the lung. Thorax 1985; 40:244-7.

29 Royal Commission on Civil Liability and Compensation for Personal Injury (chairman Lord Pearson). Report. London: HMSO, 1978:172-3. 